

\section{DISCLAIMER}

This report was prepared as an account of work sponsored by an agency of the United States Government. Neither the United States Government nor any agency Thereof, nor any of their employees, makes any warranty, express or implied, or assumes any legal liability or responsibility for the accuracy, completeness, or usefulness of any information, apparatus, product, or process disclosed, or represents that its use would not infringe privately owned rights. Reference herein to any specific commercial product, process, or service by trade name, trademark, manufacturer, or otherwise does not necessarily constitute or imply its endorsement, recommendation, or favoring by the United States Government or any agency thereof. The views and opinions of authors expressed herein do not necessarily state or reflect those of the United States Government or any agency thereof. 


\section{DISCLAIMER}

Portions of this document may be illegible in electronic image products. Images are produced from the best available original document. 


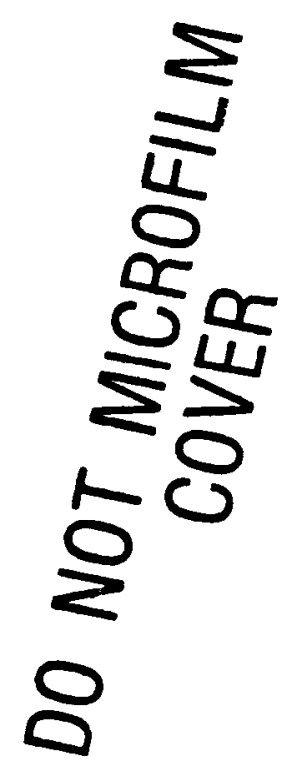

\section{LEGAL NOTICE}

This book was prepared as an account of work sponsored by an agency of the United States Government. Neither the United States Government nor any agency thereof, nor any of their employees, makes any warranty, express or implied, or assumes any legal liability or responsibility for the accuracy, completeness, or usefulness of any information, apparatus, product, or process disclosed, or represents that its use would not infringe privately owned rights. Reference herein to any specific commercial product, process, or service by trade name, trademark, manufacturer, or otherwise, does not necessarily constitute or imply its endorsement, recommendation, or favoring by the United States Government or any agency thereof. The views and opinions of authors expressed herein do not necessarily state or reflect those of the United States Government or any agency thereof.

Printed in the United States of America Available from

National Technical Information Service

U.S. Department of Commerce

5285 Port Royal Road

Springfield, VA 22161

Price Code: A03

Lawrence Berkeley Laboratory is an equal opportunity employer. 
This report was prepared as an account of work sponsored by an agency of the United States Government. Neither the United States Government nor any agency thereof, nor any of their employees, makes any warranty, express or implied, or assumes any legal liability or responsibility for the accuracy, completeness, or usefulness of any information, apparatus, product, or process disclosed, or represents that its use would not infringe privately owned rights. Reference herein to any specific commercial product, process, or service by trade name, trademark, manufacturer, or otherwise does not necessarily constitute or imply its endorsement, recommendation, or favoring by the United States Government or any agency thereof. The views and opinions of authors expressed herein do not necessarily state or reflect those of the United States Government or any agency thereof.

LBL-18520

\title{
TECHNOLOGY TRANSFER REPORT: FEASIBIIITY STUDY FOR THE USE OF GEOTHERWAL BRINE IN THE ASHDOD \\ AREA, ISRAEL
}

\author{
S.M. Benson
}

\author{
Earth Sciences Division \\ Lawrence Berkeley Laboratory \\ University of California \\ Berkeley, California
}

August 1984

This work was supported by the Assistant Secretary for Conservation and Renewable Energy, Office of Renewable Technology, Division of Geothermal and Hydropower Technologies, through U.S. Department of Energy Contract No. DE-AC03-76SF00098. 
TABLE OF CONTENTS

$\begin{array}{ll}\text { SUMMARY } & 1\end{array}$

BACKGROUND

Data Base 5

Energy Requirements for Desalination 6

Estimated Cost of Geothermal Energy

CURRIFT STATUS OF THE EVALUATION

OF THE HYDROTHERTAL POTENTIAL

Geology 8

Temperature Distribution

Extent of the Jurassic Aquifer

Hydrologic Properties 15

Brine Chemistry 20

RECONPLETION AND TESTING OF ASHDOD 3 AND 4

Ashdod 3

- Drilling and Completion 22

- Recompletion 23

- Injection Tests 26

- Airlift Test 26

- Well Stimulation 26

Ashdod 4

- Drilling and Completion 29

- Recompletion 29

- Injection Tests 31

Summary $\quad 31$

CONCLUSTON 33

REFTEREANCES

ACKNOWIEDGEMIPNTS 37 


\section{LST OF ILUSTRATIONS}

Figure 1. Geological cross section of the Jurassic aquifers underlying the Ashdod area (data from OEL, Geological Completion Reports, Ashdod 1-6)

Figure 2. Well locations, Ashdod 1-6

\section{Figure 3.}

Stabilized temperature profiles from Ashdod 3 and 4

Figure 4.

Structure and extent of the Jurassic aquifer (data and plate

Figure 5. after Michelson, 1981)

Geophysical logs from Ashdod 3, indicating possible and

Figure 6.

Ashdod 3 well construction

24

Figure 7.

Perforated interval in Ashdod 3

25

Figure 8.

Ashdod 4 well construction

\section{WST OF TABLES}

Table 1.

Parametric study of the cost of geothermal energy

7

Table 2.

Depths and thickness of the Zohar, Karmon, and Sherderot formations in the Ashdod wells (data from OEL, Geological Completion Reports)

Table 3.

Chemical analyses of the water-cut from Ashdod 2 and 5 (data from the Israel Institute of Petroleum, 1982) 


\section{SUMLARY}

The hydrothermal potential of the Ashdod area, Israel, was evaluated to determine its suitability as the low grade energy source required to operate the Ashdod desalination plant. Sw ptan, though novel, is not untike tilization of tow-to-moder ate temperature bydpothermal resources throughout tho world for spee hating, do tie hot-water anda variety of smatt-scate- industrial uses (Gudmumdsson and Palmason, 1981). An estimated 1250 cubic meters per hour of $120^{\circ} \mathrm{C}$ brine would be adequate to supply the hot water necessary for operating the desalination plant (ffoifman, 1900) A preliminarystudy, besed i.

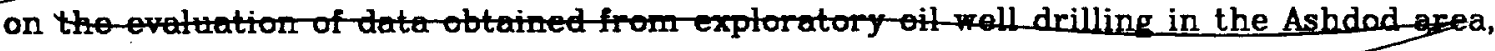
indicated the likelihood of temperatures from 110 to $115^{\circ} \mathrm{C}$ in the Jurassic limestones and dolomites at depths of 2200 to $2700 \mathrm{~m}$ (Koifman 1979). In addition, drilling and geologic data provide evidence that these fornations contain highly permeable fractures and karstic vugs (Koifman, 1979). Based on this information, and the apparent attractive economics of explgiting this resource, plans were initiated to evaluate more thoroughly the potentiak the thoifman, 1980).

Considerable interest in oil exploration in the Ashdod area resulted in the drilling of six wells into the Jurassic formations by Oil Exploration (Investments) Ltd. (OEL) in 19761980. A small amount of oil was found in two wells. Ashdod 2 and 5 . The remaining wells were abandoned as "dry holes". Evaluation of the drill cuttings, cores, and the electric logs defined two lithologic units of potential interest for hydrothermal exploitation, the Zohar and Shderot Dolomites. The formations arested by marlstones, called the Karmon Shales. The Zohar and Karmon Formations, begtining at a depth of approximatoly 2575 fr. are approximately 75 and $50 \mathrm{~m}$ thick, respectively. As the Shderot Formation was never completely penetrated, its thickness is unknown.

To the west and south the formation are bounded by an unconformity that is overlain by thick marls and shates (Michelson, 1981). The eastern boundary of the hydrologic system is created by a mineratome from the dolomitic rocks near As the 
chalky limestone found at Givati (Michelson, 1981). The extent of these formations to the north is uncertain due to a lack of deep well data. Estimates of the areal extent of these formations, which comprise the Jurassic aquifer, range from 40 to 75 square $\mathrm{km}$ (Michelson, 1981).

In order to further evaluate the hydrothermal potential of the Jurassic formations, two of the OEL wells, Ashdod 3 and 4, were recompleted for the purposes of hydrologic testing and temperature logging. After recompletion, temperature logging indicated maximum bottom hole temperatures of 92 and $85^{\circ} \mathrm{C}$, respectively for Ashdod 3 and 4 . The projected maximum aquifer temperature, based on these data, is $95^{\circ} \mathrm{C}$ at a depth of $2700 \mathrm{~m}$. The lower-than-anticipated temperature of the geothermal fluid increased the estimated hot water requirements from the initial value of 1250 to 2000 cubic meters $/ \mathrm{hr}$. Consequently, the economic outlook of the project changed considerably.

Hydrologic testing of wells Ashdod 3 and 4, to determine the hydraulic properties of the formations and well deliverability was thwarted by extremely poor well performance. After the workover operations, it was determined that the connection between the well and formation was very poor in both wells. The plugging was most likely due to a combination of factors, including: use of loss-of-circulation fluid additives during the original drilling of the well; chemical incompatibility between in situ and drilling fluids; swelling of bentonite and formation clays; sloughing of the well-face; and mechanical plugging of the perforations. Remedial action to correct these problems was designed but never implemented due to a change in program plans.

Investigation of the hydrothermal potential of the Jurassic formations underlying the Ashdod area has revealed that the aquifer temperatures range between 85 and $92^{\circ} \mathrm{C}$. The hydrologic parameters are not well defined; however the matrix permeability of the dolomites and limestones is probably between 1 and $10 \mathrm{md}$. This is insufficient permeability for a large scale pumping operation such as the one required to operate the desalination plant. Therefore, successful utilization of the resource requires the presence of 
significant fractures and/or connected vugs in the formation. Evaluation of the well logs and cores indicates a significant degree of fracturing in the formation, particularly at the contacts between formations. This phenomenon is typical of karstic formations in limestones and therefore, a likely possibility in this area. The permeability of the fractured and vuggy intervals is not known at this time. However, the very low well productivity and formation plugging may indicate that permeability of the fracture zones may easily be impaired, suggesting that the fracture zones are not suitable production intervals. Until a test is conducted on a properly completed well, it is not possible to evaluate the deliverability of wells tapping these aquifers.

The probable extent of the Zohar and Shderot Formations has been determined. However, the size of the reservoir is not so critical to the successful utilization of the resource because reinjection for pressure maintainance will certainly be required for successful resource development. In summary, more information about the resource and its potential for development is available than in the past, but a good deal more is required before any proposed development scheme can be considered seriously. 


\section{BACKGROUND}

On the recommendation of the Israeli Institute of Petroleum and Energy, a preliminary assessment of the potential and passible utilization of geothermal resources in the Southern Coastal Plain was undertaken in 1978 (Koifman, 1979). This study, and a second one the following year, provided the initiative for considering the use of geothermal brine as the heat source for running the desalination plant (Koifman, 1980). The study included the evaluation of bottom hole temperatures, temperature profles, and the loss of circulation of drilling fluids in 48 deep oil exploration wells in the Southern Coastal Plain of Israel.

Of particular interest was the evaluation of data from six wells drilled by the OEL into the Jurassic formations in the Ashdod area. The Jurassic formations in this area, beginning at depths greater than $2 \mathrm{~km}$, consist of dolomites, limestones and marlstones. Two lithologic units, with a combined thickness of at least $100 \mathrm{~m}$ were identified as potential geothermal aquifers: the Zohar Dolomite, the Karmon Shales (marlstone), and the Shderot Dolomite. Core data, electric logs and loss-of-drilling fluids indicated that the contacts between these units were fractured and/or vuggy. Based primarily on the evaluation of data from the OEL wells, the investigation concluded that hot, mineralized water could be produced in large quantities from the Jurassic formations in the Ashdod area. Estimated temperatures ranged from 110 to $115^{\circ} \mathrm{C}$ at depths of 2200 to $2700 \mathrm{~m}$. Temperatures as high as $140^{\circ} \mathrm{C}$ were anticipated at depths of $3500 \mathrm{~m}$.

Several possible uses for the potential geothermal resource were identified by Koifman (1979 and 1980) and included: generation of electricity, space heating, green house heating, and desalination. The close proximity of the Ashdod desalination plant to the study area and the necessity of finding an alternative energy supply for the plant, led to a detailed economic evaluation of the viability of using geothermal brine as the low grade heat source for operating the plant. Economic analyses based on a geothermal resource with temperatures of 110 to $130^{\circ} \mathrm{C}$ indicated that sea-water desalination using the "Zarchin Process" coupled with an energy source such as that anticipated in the Ashdod area 
would provide one of the least expensive sources of desalinated water on the market (Koif$\operatorname{man}, 1980)$.

The attractiveness of the resource and identification of a viable end-use resulted in the more extensive geothermal reservoir investigation undertaken by the Joint U.S.Israeli Desalination Project. The reservoir assessment program, the main subject of this report, included re-evaluation of well data from the exploratory oil wells, recompletion of wells Ashdod 3 and 4, hydrologic testing, and reservoir modeling. Detailed reports were prepared on each of these topics, insofar as they were completed, and this report will rely heavily on references to this material. It is the purpose of this report to summarize the material and to provide documentation and assessment of the hydrothermal potential at Ashdod. References to relevant background and reference material are made when appropriate.

\section{Data Base}

With the exception of information obtained from the recompletion of wells Ashdod 3 and 4 , the data upon which this study was based came from six existing deep exploratory wells, drilled by OEL, in search of hydrocarbon deposits. Although extensive evaluation of the resource had been previously carried out by OEL, the emphasis of their analysis was somewhat different than that required for evaluating the hydrothermal potential. In general, successful exploitation of a geothermal resource depends on locating a relatively large volume of reservoir rock with an adequate distribution of permeability throughout the formation. Rarely is one fracture, or one fractured interval, capable of sustaining the production rate required for geothermal development. For this reason, little emphasis is placed on the detailed evaluation of a single feature. Instead, an attempt is made to characterize the system as a whole and to obtain the bulk averages of the physical properties. The physical parameters critical to the viability of utilization of this resource are the degree and distribution of highly permeable fractures (or interconnected vugs), and a 
sufficiently high reservoir temperature.

\section{Energy Requirements for Desalination}

The estimated geothermal brine requirements for operating the desalination plant are based on the assumption that a total of 75 million kcal/hr are needed to heat the incoming sea water. Assuming a reservoir temperature of $95^{\circ} \mathrm{C}$ and a reject brine temperature of $60^{\circ} \mathrm{C}$, approximately $2000 \mathrm{~m}^{3} / \mathrm{hr}$ of geothermal brine are required to supply the necessary heat. Due to chemical characteristics of the brine, a heat exchanger may be required. Use of a heat exchanger would require $2140 \mathrm{~m}^{3} / \mathrm{hr}$ as opposed to $1970 \mathrm{~m}^{3} / \mathrm{hr}$ per hour for direct utilization (J. Finke, personal communication).

\section{Estimated Cost of Geothermal Energy}

Preliminary estimates of the cost of using geothermal energy for the desalination process were made using a variety of assumptions regarding wellfield requirements, well drilling costs, and the heat transfer mechanism. Results of the analysis are given in Table 1. Cost estimates range from $\$ 4.70$ to $\$ 8.80$ per million kcal. The number of wells needed to supply the brine is the single most important parameter in determining the cost of the project. The viability of using the brine depends heavily on the availability of wells with very high productivities ( 4.00 to $500 \mathrm{~m}^{3} / \mathrm{hr} /$ well). The focus of the resource assessment was therefore being directed toward determining the possibility of drilling and completing such wells in the Jurassic formations underlying the Ashdod area. 


\section{GRFP - ALTERRATIVE ESTUTATES OF ENERGY}

(all estimates based on $75 \times 10^{6} \mathrm{kcal} / \mathrm{hr}$ or $60 \times 10^{10} \mathrm{kcal} / \mathrm{yr}$ )

Case number

Brine temperature, ${ }^{\circ} \mathrm{C}$

Reject temperature, ${ }^{\circ} \mathrm{C}$

Total flow, $\mathrm{m}^{3} / \mathrm{hr}$

Pumping head, m

Number of producing wells

Number of injection wells

Number of dry holes

Heat transfer

Brine treatment cost, US\$ $/ \mathrm{m}^{3}$

Capital cost, US\$ $\$ 10^{6}$

Annual costs, enery, O\&CM US\$/yr

Total unit cost, ${ }^{\mathrm{C}} \mathrm{US} \$ / 10^{6} \mathrm{kcal}$

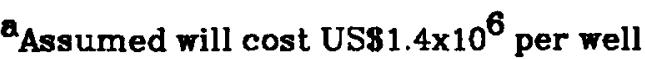

bAssumed will cost US\$1.7 $\times 10^{6}$ per well.

CIncludes: Amortization and depreciation@10\%/yr;overhead@10\%

\begin{tabular}{ccccc}
1 & 2 & 3 & 4 & 5 \\
95 & 95 & 95 & 95 & 85 \\
60 & 57 & 57 & 57 & 60 \\
2140 & 1970 & 1970 & 1970 & 2140 \\
300 & 300 & 300 & 400 & 400 \\
5 & 4 & 5 & 4 & 8 \\
3 & 3 & 5 & 3 & 6 \\
2 & 1 & 2 & 1 & 3 \\
Ht Exch & Flash & Flash & Flash & Ht Exch \\
.05 & .02 & .02 & .02 & .02 \\
$17.4^{1}$ & $12.0^{\mathrm{a}}$ & $22.0^{\mathrm{b}}$ & $13.1^{1}$ & $32.0^{\mathrm{b}}$ \\
\hline $2.0 \times 10^{6}$ & $1.3 \times 10^{6}$ & $1.3 \times 10^{6}$ & $1.5 \times 10^{6}$ & $1.6 \times 10^{6}$ \\
6.80 & 4.70 & 6.70 & 5.20 & 8.80
\end{tabular}

Table 1. PARA IEIRC STUDY OF THE COSTS OP GEOTHDRTAL ENERGY

(from J. Finke, 1982). 


\section{CURRENT STATUS OF THE EVALUATION \\ OF THE HYDROTHERMAL POTENTIAL.}

The following sections summarize the results of the investigation carried out as part of the reservoir assessment program undertaken by the U.S. - Israeli Desalination Project. The study included: i) re-evaluating the geological data from the Ashdod wells, ii) temperature logging of Ashdod 3 and 4, iii) determining the extent of the potential aquifer based on analysis of well data from the Ashdod, Gan Yavne and Givati fields, iv) analyzing hydrological data, and v) re-evaluating geochemical data. Also, wells Ashdod 3 and 4 were recompleted for purposes of hydrologic testing and temperature logging. This work is discussed separately in the section of this report entitled Recompletion and Testing of Ashdod 3 and 4.

\section{Geology}

The Ashdod wells penetrate a thick sequence of primarily carbonate rocks. Figure 1 shows a schematic of the horizons of potential interest, which include the Zohar Dolomites, the Karmon Shales, and the Shderot Dolomites. Depths and thicknesses of these formations are summarized in Table 2. Locations of the 6 wells from which the cross section was developed are shown in Figure 2. The wells are located near the transition, in the lower Cretaceous, between the Judea limestone facies and the Talme Yafe fine carbonate clastics to the west (Koifman, 1979). The contact between the Cretaceous and Jurassic strata is an unconformity, indicating that karstic activity may have taken place below the erosional surface (Koifman, 1979; Michelson, 1981). The Jurassic formations are faulted, with both anclent and more recent activity creating normal offsets between lithologic units (Koifman, 1979). The major faults have a WSW-ENE trend. Some minor faulting with a NorthSouth trend may also be present in the area (Koifman, 1979).

The lithologic units of interest to this study are the lower members of the Jurassic formation, which includes the Beer Sheva, Kidod, Zohar, Karmon, and Shderot. In the 


\begin{tabular}{|c|c|c|c|c|c|c|}
\hline & Ashdod 1a & Ashdod 2 & Ashdod 3 & Ashdod 4 & Ashdod 5 & Ashdod 6 \\
\hline Top of Zohar & $2564 \mathrm{~m}$ & $2536 \mathrm{~m}$ & $2553 \mathrm{~m}$ & $2535 \mathrm{~m}$ & $2538 \mathrm{~m}$ & $2526 \mathrm{~m}$ \\
\hline Thickmess & $57 \mathrm{~m}$ & $\begin{array}{c}\text { not } \\
\text { penetrated }\end{array}$ & $67 \mathrm{~m}$ & $85 \mathrm{~m}$ & $80 \mathrm{~m}$ & $84 \mathrm{~m}$ \\
\hline Top of Karmon & $2621 \mathrm{~m}$ & & $2620 \mathrm{~m}$ & $2610 \mathrm{~m}$ & $2618 \mathrm{~m}$ & $2620 \mathrm{~m}$ \\
\hline Thickneas & $67 \mathrm{~m}$ & & $45 \mathrm{~m}$ & $40 \mathrm{~m}$ & $40 \mathrm{~m}$ & $38 \mathrm{~m}$ \\
\hline Top of Shderot & $2628 \mathrm{~m}$ & & $2665 \mathrm{~m}$ & $2650 \mathrm{~m}$ & $2658 \mathrm{~m}$ & $2658 \mathrm{~m}$ \\
\hline
\end{tabular}

Ashdod area, only some of these formations are penetrated by all of the wells because of the truncation of the upper formations to the north-west. For purposes of this study it was assumed that the Kidod Formation, a shale (marlstone), acts as a cap to the units below. The Zohar, directly below the Kidod Formation, is composed of porous and irregularly fractured dolomite. At the upper contact large vugs are present, resulting in a complete loss of drilling fluid circulation, in three of the six wells drilled (OEL, Drilling and Geological Completion Reports, Ashdod 1-6). Some of the vugs and fractures are filled with calcite, anhydrite, and quartz (OEL, Drilling and Geological Completion Reports, Ashdod 1-6). The Karmon Formation separates the two dolomite units. Although called a shale, the formation is actually a dense marly limestone (OEL, Drilling and Geological Completion Reports, Ashdod 1-6). Evaluation of electric log data indicates that this unit may also be somewhat fractured and vuggy, and therefore, may contribute to the hydrothermal potential. The Shderot Formation, underlying the Karmon, is a somewhat denser dolomite than the Zohar. Although the upper section of this formation is somewhat vuggy, it is less so than the Zohar (Michelson, 1981). The lower Shderot is dense and compact dolomite. Loss of drilling fluid circulation was also encountered at the top of the Shderot Formation. 


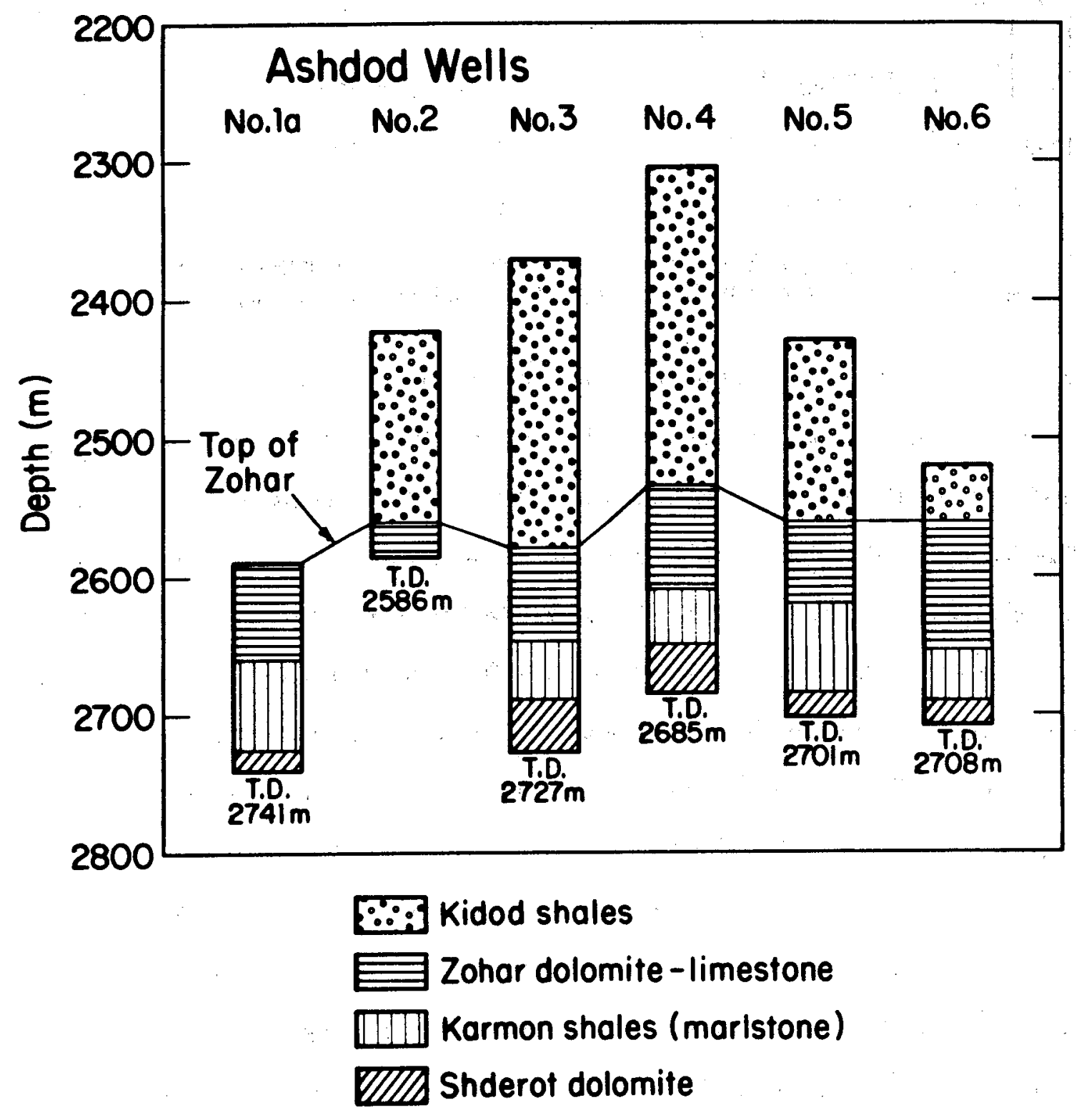

XBL 848-9855

Figure 1. Geological cross section of the Jurassic aquifers underlying the Ashdod area (data from OEL, Geological Completion Reports, Ashdod 1-6). 


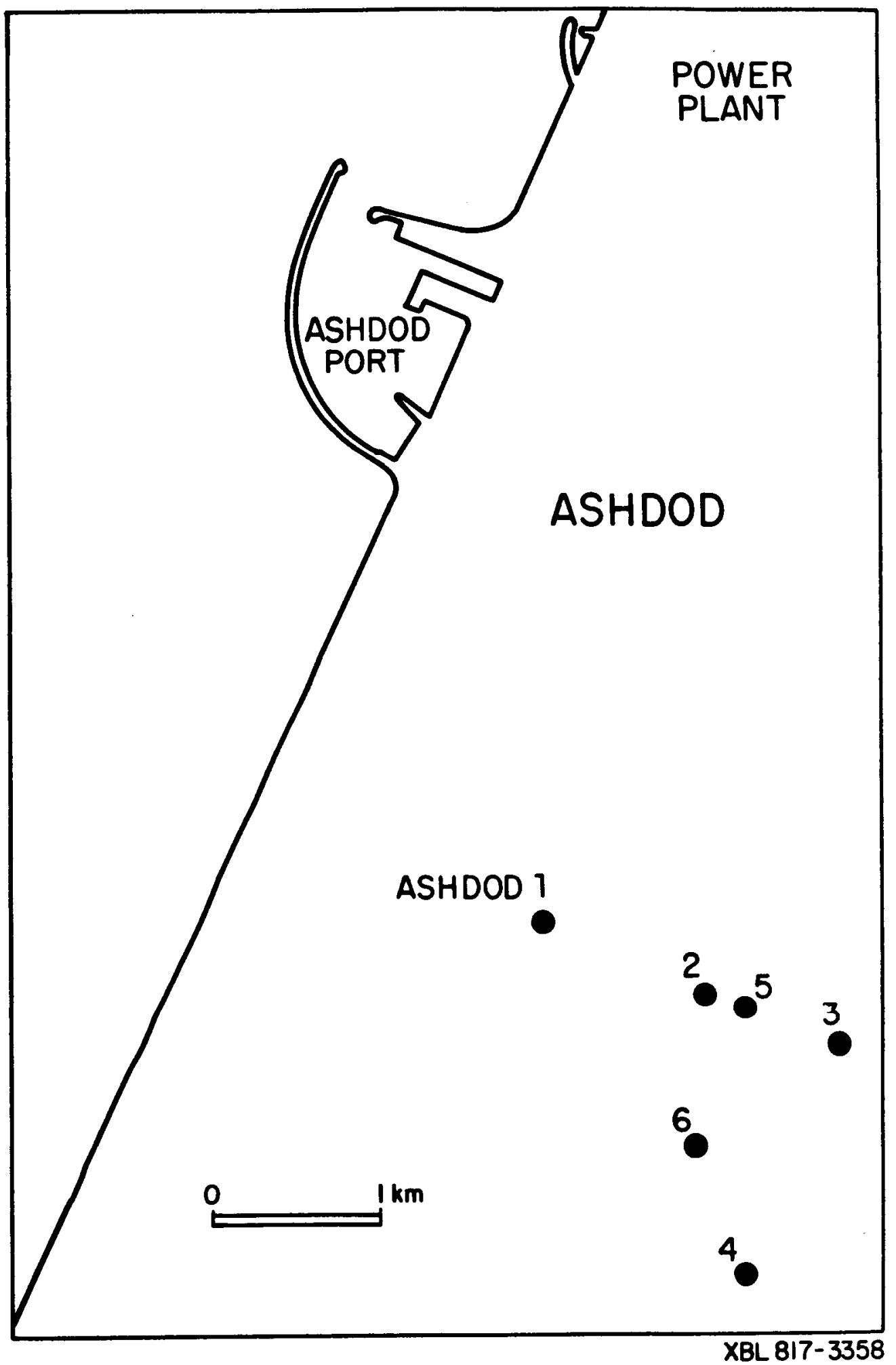

Figure 2. Well locations, Ashdod 1-6. 


\section{Temperature Distribution}

Preliminary estimates of the temperatures in the Jurassic aquifers underlying the Ashdod area were obtained by examining electric logs and drilling-mud temperature data from 48 wells that penetrate or nearly penetrate the Jurassic formations (Koifman, 1979). Temperatures in the range of 110 to $115^{\circ} \mathrm{C}$ were predicted at depths of 2600 to $2800 \mathrm{~m}$ based on the assumptions that: 1) actual formation temperatures would be $25^{\circ} \mathrm{C}$ higher than those measured during or shortly after drilling, and ii) the geothermal gradient in the Jurassic dolomites is $3.5^{\circ} \mathrm{C} / 100 \mathrm{~m}$ (Koifman, 1979). Temperatures as high as $140^{\circ} \mathrm{C}$ were anticipated at a depth of $3500 \mathrm{~m}$ (Koifman, 1979).

After wells Ashdod 3 and 4 were recompleted, temperature logs were run (Figure 3). These surveys were obtained one and two months, respectively, after the recompletion of Ashdod 3 and 4, and should be considered as true indicators of the formation temperatures. Maximum temperatures of $92^{\circ}$ and $85^{\circ} \mathrm{C}$ were measured in Ashdod 3 and 4, respectively, indicating an average geothermal gradient for the area of $2.7^{\circ} \mathrm{C} / 100 \mathrm{~m}$. Slight variations in the gradient, with depth, correlate with the different lithogic units penetrated by the wells. As expected, the gradient in the compacted carbonate units is greater than in the marlstones (Koifman, 1979).

The near-normal geothermal gradient for this area indicates that the existence of the hydrothermal system is not related to a temperature anomaly or ongoing tectonic processes in the area. Instead, the temperatures encountered in the Jurassic formations are nearly the same as those expected anywhere in the world at that depth. The boundaries of the potentially exploitable resource are therefore governed by hydrologic and structural constraints rather than the extent of a thermal anomaly (IDO, 1982). 


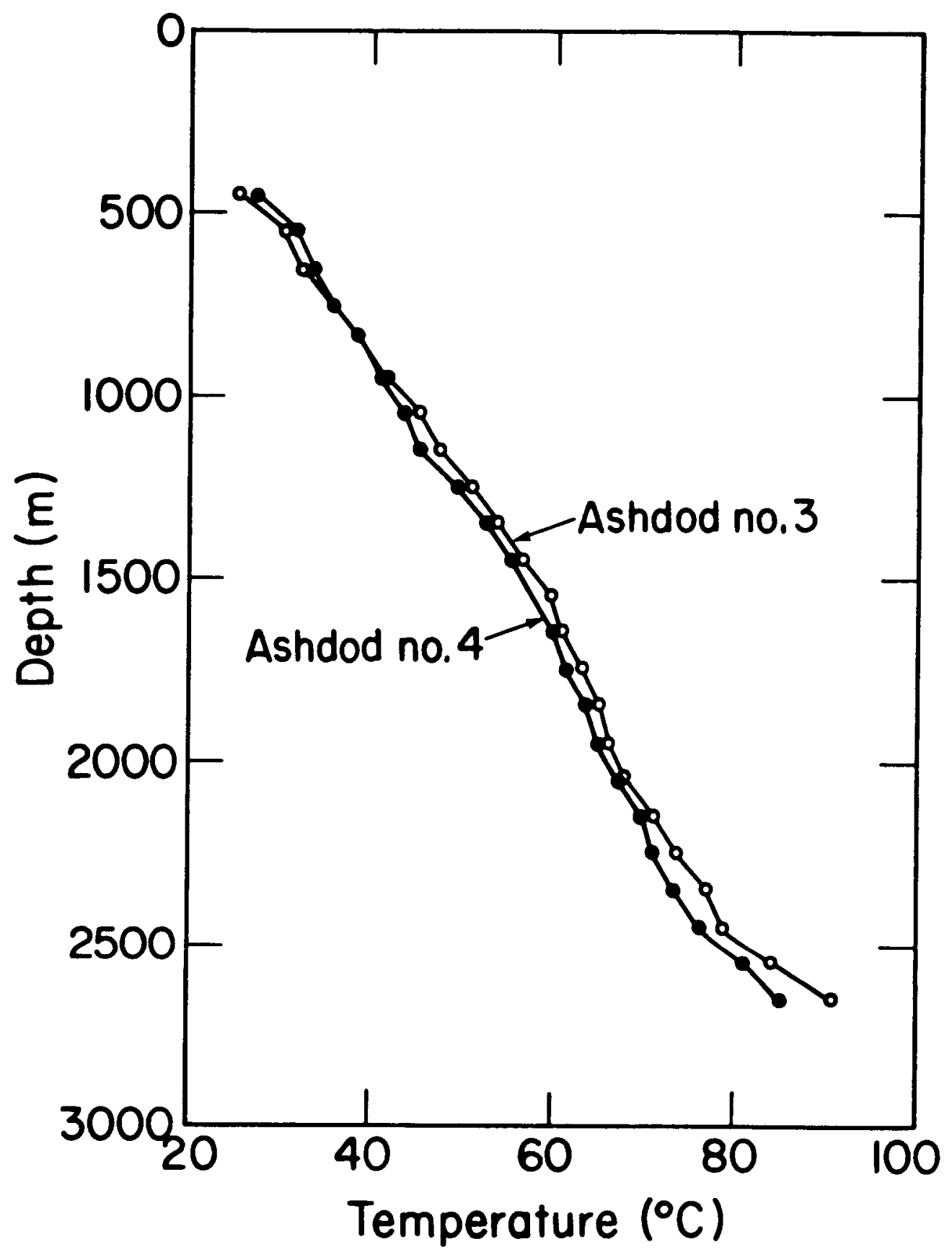

XBL 848-9866

Figure 3. Stabilized temperature profiles from Ashdod 3 and 4. 
The large difference between anticipated and actual formation temperatures shows the risk of using unstabilized wellbore temperatures to predict stabilized formation temperatures. The rate and extent of temperature stabilization is influenced by many factors that are difflcult to account for (e.g., drilling rate, loss-of-circulation, formation properties, etc.). Therefore, only by direct measurement of the wellbore temperature, after a suitable period of stabilization, is it possible to determine the true formation temperature.

\section{Extent of the Jurassic Aquifer}

The size of the exploitable aquifer is governed primarily by the distribution of permeable strata and/or fractures in the Jurassic formations. Based on this criterion, well data from the Ashdod and Gan Yavne wells were evaluated to locate the hydrologic boundaries to the aquifer (Michelson, 1981; Koifman, 1979 and 1980). The permeability of the Jurassic formation results mainly from fractures, joints and interconnected vugs in the matrix material (OEL, Drilling and Geological Completion Reports, Ashdod 1-6; Koifman, 1979 and 1980; Michelson, 1981). For purposes of this study, the absence of features in core and well data was used as a boundary criterion for the system. However, it is worth mentioning that very low permeability rocks, with a large contact area to strata of higher permeability, can add tremendously to both the storage volume and potential of a resource (Warren and Root, 1963). This factor was not considered when the extent of the Jurassic aquifer was evaluated.

The Jurassic aquifer can be divided into three sub-units: the upper sub-aquifer (Zohar), an aquiclude (Karmon), and the lower sub-aquifer (Shderot). Hydrologically, the aquifer is thought to be bounded by impermeable strata on all sides. To the west and south these formations are truncated and overlain by the thick marls and shales of the Talme Yaffe Formation (Michelson, 1981). The eastern boundary, although not precisely located, is created by a mineralogic transition from the dolomitic formations at Ashdod to the 
chalky limestones found in Gan Yavne (Michelson, 1981). To the north it is presumed that the southern border fault of the Palmahim acts as a hydrologic boundary. Figure 4 shows the proposed hydrologic boundaries of the system. Estimates of the areal extent of the system, based on these criteria, range from 40 to 75 square $\mathrm{km}$ (Michelson, 1981).

\section{Hydrologic Properties}

Hydrologically these dolomitic formations are characterized as a double-porosity system. That is, an aquifer in which the bulk of the fluid is stored in the low permeability rock matrix while the fractures and vugs provide the permeable pathways along which the fluid moves to the well (Warren and Root, 1963; Earlougher, 1977). Evaluation of such sytems requires knowledge of the hydraulic properties (permeability and porosity) of both the rock matrix and high permeabilty conduits. The permeability and porosity of the matrix material (dolomite) can be determined from laboratory measurements of rock core samples. On the other hand, accurate measurement of the hydraulic properties of the fractures and vugs can only be obtained by field testing. As a number of cores were obtained during drilling of the Ashdod wells, laboratory measurements to determine the properties of the rock matrix have been performed. To date, there are little, if any, field test results from which the properties of the fracture system can be evaluated. Drill stem tests, injection tests, and an airlift have been performed; all have had limited success or applicabilty for purposes of this investigation. A long term (one month) interference test, during which a large volume of the reservoir is stressed, is required to assess the hydraulic properties of the system as a whole. Such a test was the goal of this project. However, very poor production, injection and observation well performance thwarted efforts to obtain such data. It was impossible to pump well Ashdod 3 or 4 at a rate sufficient 


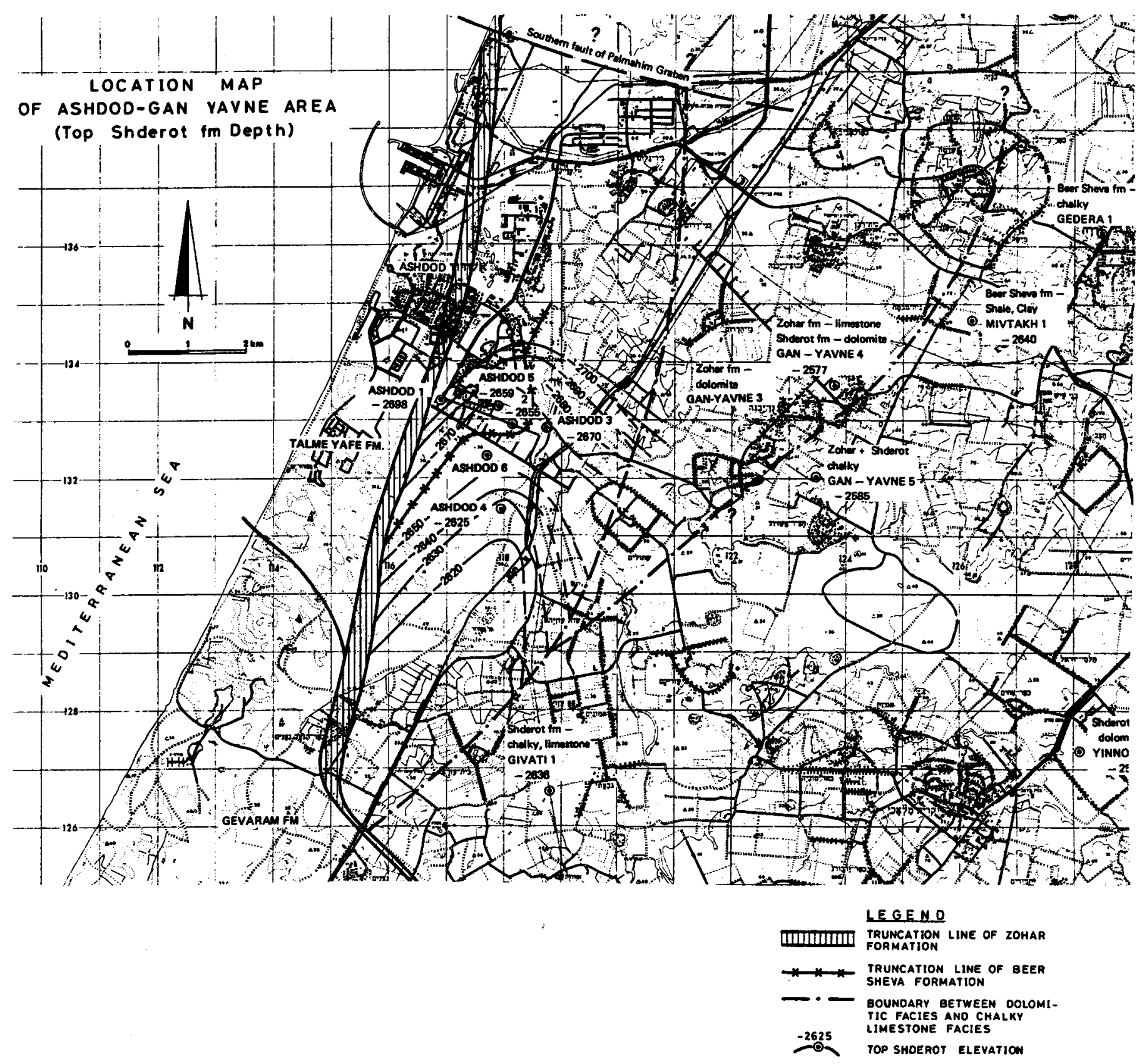

Figure 4. Structure and extent of the Jurassic aquifer (data and plate after Michelson, 1981). 
to collect reliable aquifer data with the wells in their present condition. Therefore, critical information, required for the appraisal of the brine resources in the Ashdod area, is unavailable.

Permeability and porosity measurements were performed on core plugs taken from the Zohar and Shderot Formations. In general, both of these parameters are highly variable, even within a single core. In particular, the presence of a single vug or fracture signiflcantly increases both the permeability and porosity. Average values of the porosity in the Zohar and Shderot are 8 and 4\%, respectively (Koifman, 1979; Michelson, 1981). For both the Zohar and Shderot Formations the permeability ranges from less than 1 to over $100 \mathrm{md}$, depending on the presence of vugs or joints in the core plug. Most likely, the average permeabilities of the Zohar and Shderot Formations, in the absence of major fractures, are 10 and 5 md, respectively (Koifman, 1979; Michelson, 1981).

Prior to and during the reservoir assessment discussed here, an airlift test and several injection tests were carried out in an attempt to determine the hydrologic properties of the Zohar and Shderot Formations (Koifman, 1980; Mercado and Simpson, 1981). All of these tests, with the exception of an injection test in Ashdod 5, were hampered by formation damage (wellbore plugging) and thermal wellbore transients. Results of these tests indicate that the well productivity and injectivity are far less than anticipated even if one assumes that no fractures intersect the wellbore. Therefore, it was concluded that the connection between the well and formation was impaired by chemical and/or mechanical causes/problems. An injection test in Ashdod 5, conducted immediately following drilling, resulted in an injectivity of $5-10 \mathrm{~m}^{3} / \mathrm{hr} /$ meter of drawdown for a $26 \mathrm{~m}$ interval in the upper Shderot (Koifman,1980; Mercado and Simpson, 1981). Injectivity of this magnitude confirms the presence of permeable fractures and interconnected vugs in the Shderot Formation. As the Zohar Formation is thought to be more fractured and vuggy than the Shderot, it can be inferred that it too has moderate-to-high injectivity. 
In the absence of more concrete data, an evaluation of the degree of fracturing, based on electric logs and geological considerations, is valuable. Core data were examined to assess the nature of the pore spaces in the rock. It was determined that the intensity of fractures and interconnected vugs in the Zohar is an order of magnitude higher than in the Shderot (Michelson, 1981). The occurrence of these features is attributed to karstic activity near the phreatic water table (Buchbinder, 1978; Derin and Gerry, 1972). The unconformity at the top of the Zohar indicates that prior to deposition of the overlying Kidod Formation, the Zohar was exposed to the atmosphere. Hence, the presence of the phreatic water table and resultant karstic structure at this interval is not unexpected. On the other hand, since the Shderot is overlain conformably by the Karmon, karstic activity in the interval is unlikely (Michelson, 1981). Permeability reduction due to recrystallization of the pore spaces has also taken place (OEL Drilling and Geological Completion Reports, Ashdod 1-6). One possible source is post-depositional hydrothermal precipitation of calcite, fluorite and other minerals (Goldberg and Bogoch, 1978).

In addition to re-evaluating the core data, electric logs from Ashdod 3 were reanalyzed to determine the extent of fracturing and karstic phenomena. Figure 5 shows a synthesis of this data, along with identification of probable and possible fractured intervals. As shown in the figure, approximately $25 \%$ of the Jurassic aquifer is likely to contain high permeability intervals. Analysis of the depositional environment, as well as electric $\log$ and core data, indicate that fracturing and karstic activity are likely to have occurred, resulting in the development of secondary permeability in the Jurassic formations underlying the Ashdod area. The high permeability strata are not limited to, but concentrated at the contacts between the formations. 


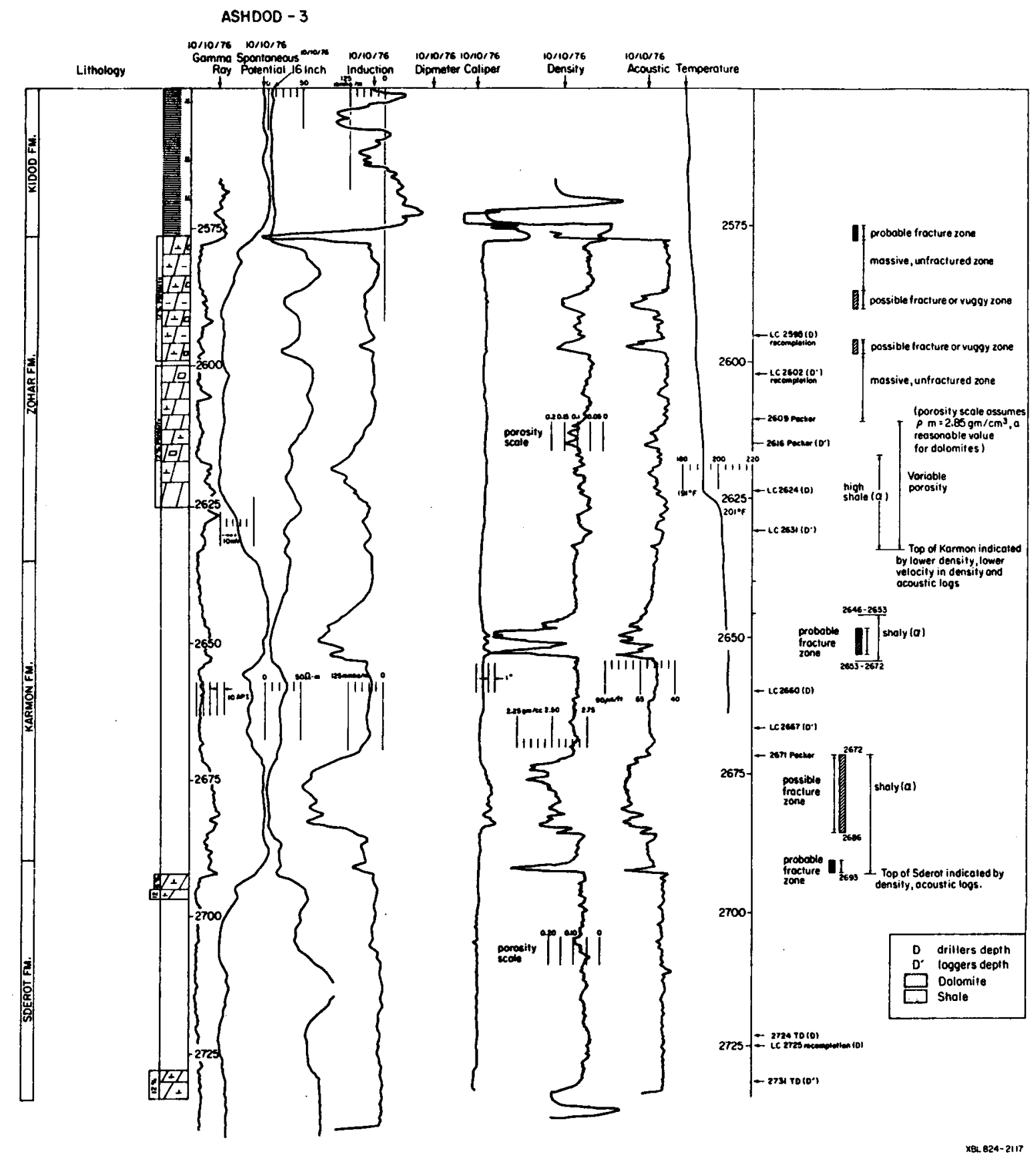

Figure 5. Geophysical logs from Ashdod 3, indicating possible and probable fractured strata. 
Although the drilling and geologic data indicate that the Jurassic formation form a potential hydrothermal aquifer, all hydrologic tests, except one, have resulted in extremely negative results. These results have been attributed to chemical incompatibility between formation and drilling fluids, as well as to mechanical problems (plugging) in the wells. Certainly some of the testing problems were due to these factors. However, the large differences between the actual well performances and the performance required for successful development of the resource ( 400 to $500 \mathrm{~m}^{3} / \mathrm{hr} /$ well), shed doubt on the possibility of completing the wells in a satisfactory manner.

\section{Brine Chemistry}

Samples of the formation fluids are available from drill-stem tests and do not include detection or measurement of the gases dissolved in the brine. The Ashdod brines are highly saline, with total dissolved solids in the range of 100,000 to $110,000 \mathrm{ppm}$. There is some indication that the Shderot Formation contains brine of higher salinity than the Zohar, but inconsistencies in the analyses do not permit verification of this observation (Starinsky and Kac, 1978). Table 3 lists the results of the chemical analyses of brine pumped from the Zohar Formation in Ashdod 2 and 5. Analyses of fluid samples from the drill-stem tests yield similar results. However, in general, the total dissolved solids content is somewhat lower $(70,000$ to $80,000 \mathrm{ppm})$ than measured in the water cut from Ashdod 2 and 5 (Koifman, 1980). Most likely, the lower salinity results from dilution of the formation fluids with drilling fluids. 
$-21-$

\begin{tabular}{|c|c|c|}
\hline Component & Ashdod $2^{*}$ & Ashdod $5 *$ \\
\hline $\mathrm{Na}$ & 24,000 & 25,000 \\
\hline $\mathbf{k}$ & 500 & 500 \\
\hline $\mathbf{L i}$ & 15 to 20 & 15 to 20 \\
\hline $\mathrm{Ca}$ & 5,500 & 6,300 \\
\hline $\mathrm{Cl}$ & 60,000 & 54,000 \\
\hline $\mathrm{SO}_{4}$ & 620 & 250 \\
\hline $\mathrm{HCO}_{3}$ & 190 & 250 \\
\hline free $\mathrm{CO}_{2}$ & 1,000 & 100 \\
\hline $\mathrm{SiO}_{2}$ & traces & traces \\
\hline TDS & 100,000 & 104,000 \\
\hline pH & 5.5 & 6.6 \\
\hline \multicolumn{3}{|c|}{ *all values in ppm } \\
\hline & $\begin{array}{l}\text { IHE WATER } \\
\text { institute of }\end{array}$ & ND 5 \\
\hline
\end{tabular}




\section{RECONPLETION AND TESTING OF WELLS ASHDOD 3 AND 4}

During this project wells Ashdod 3 and 4 were recompleted for use as production, observation and/or injection wells. After recompletion, injection tests were conducted in both wells. A short airlift was also conducted in Ashdod 3. This section of the report summarizes the activities at Ashdod 3 and 4 and discusses their current status. As mentioned previously, the wells are in very poor condition. A remedial treatment to improve the condition of Ashdod 3 was designed but never carried out due to program changes. A description and discussion of the rehabilitation program is also given here.

\section{Well Ashdod 3}

\section{Drilling and Completion}

Ashdod 3 was spudded on July 12, 1976 and completed to a depth of $2724 \mathrm{~m}$ on October 22, 1976. The Zohar Formation was penetrated with little difficulty; however, the Karmon and upper Shderot were drilled without any circulation. Numerous attempts to plug the loss-of-circulation zones with diesel bentonite plugs and cement failed. During this period, large quantities of material (e.g., cement, bentonite, chemicals(?)), capable of creating extensive formation damage, were injected into the formation. Although not capable of plugging the formation in the short term, the long term effects and interactions between the injected materials and the formation may have initiated formation and wellbore damage. A $95 / 8$ inch (40\#-k55) casing was set and cemented from the surface to a depth of $2092 \mathrm{~m}$. After determining that the well was a "dry hole", a cement plug was set at $2090 \mathrm{~m}$. The well was then perforated at a depth of $270 \mathrm{~m}$ in order to test a shallow zone for the presence of hydrocarbons. The well was subsequently abandoned. 


\section{Recompletion}

Workover operations on Ashdod 3 began on May 5, 1981. Unexpectedly, the top $312 \mathrm{~m}$ of the well was fllled with cement. After drilling out the cement and removing a large piece of iron from the well, the drill pipe was circulated to a depth of $2028 \mathrm{~m}$, where a hard cement plug was encountered. Drilling out cement continued to a depth of $2088 \mathrm{~m}$. Below this depth the well was flled with cavings. At a depth of $2595 \mathrm{~m}$, a complete loss of circulation occurred and the well was reamed with no returns to the depth of $2731 \mathrm{~m}$. During this time a total of $355 \mathrm{~m}^{3}$ of fresh water was lost into the formation. The well was enlarged with an $1 / 2$ inch bit, during which time drilling mud was used. This time full returns were obtained. The 7-inch liner (20\#-k55), shown schematically in Figure 6, was lowered into the well to stabilize the hole and isolate the Shderot Formation. Three packers were set in the hole; the lower two packers isolate the Zohar, so that it also could be tested. A rathole was then drilled to a total depth of $2740 \mathrm{~m}$ with full returns. The final well completion of Ashdod 3 is shown in Figure 6.

After drilling the rathole the wellbore was cleaned with fresh water before perforating the liner between the lower two packers. A total of 280 holes were shot into the liner adjacent to the Zohar Formation between 2616 and $2628 \mathrm{~m}$. depth. Contrary to expectations, the fluid level in the wellbore did not drop after the well was perforated. Instead, the wellbore remained full, indicating the formation and perforations were at least partially plugged. Applying 250 psi at the wellhead broke down the plugging. An injection test, discussed in the next section, was then conducted. During the injection test 1350 gallons of $16 \% \mathrm{HCl}$ acid and inhibitor were injected into the formation. The acidification seemed to improve the well injectivity but an airlift test, conducted approximately one month later, indicated that the well was plugged again. The liner in Ashdod 3 was perforated on several occasions. Figure 7 shows all of the perforated intervals and the shot density in each of them. The final workover was completed on May 26, 1981. 


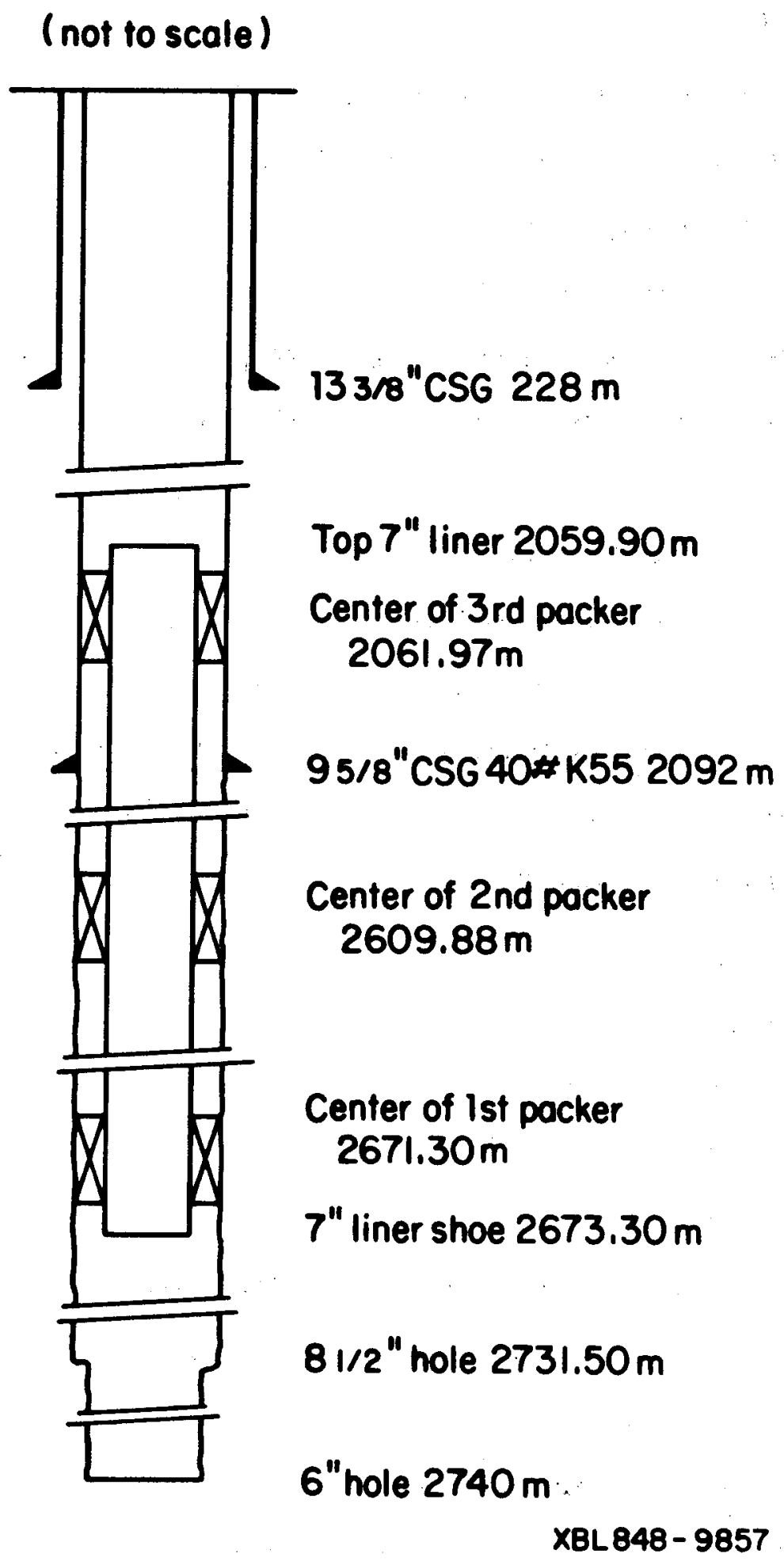

Figure 6. Ashdod 3 well construction. 


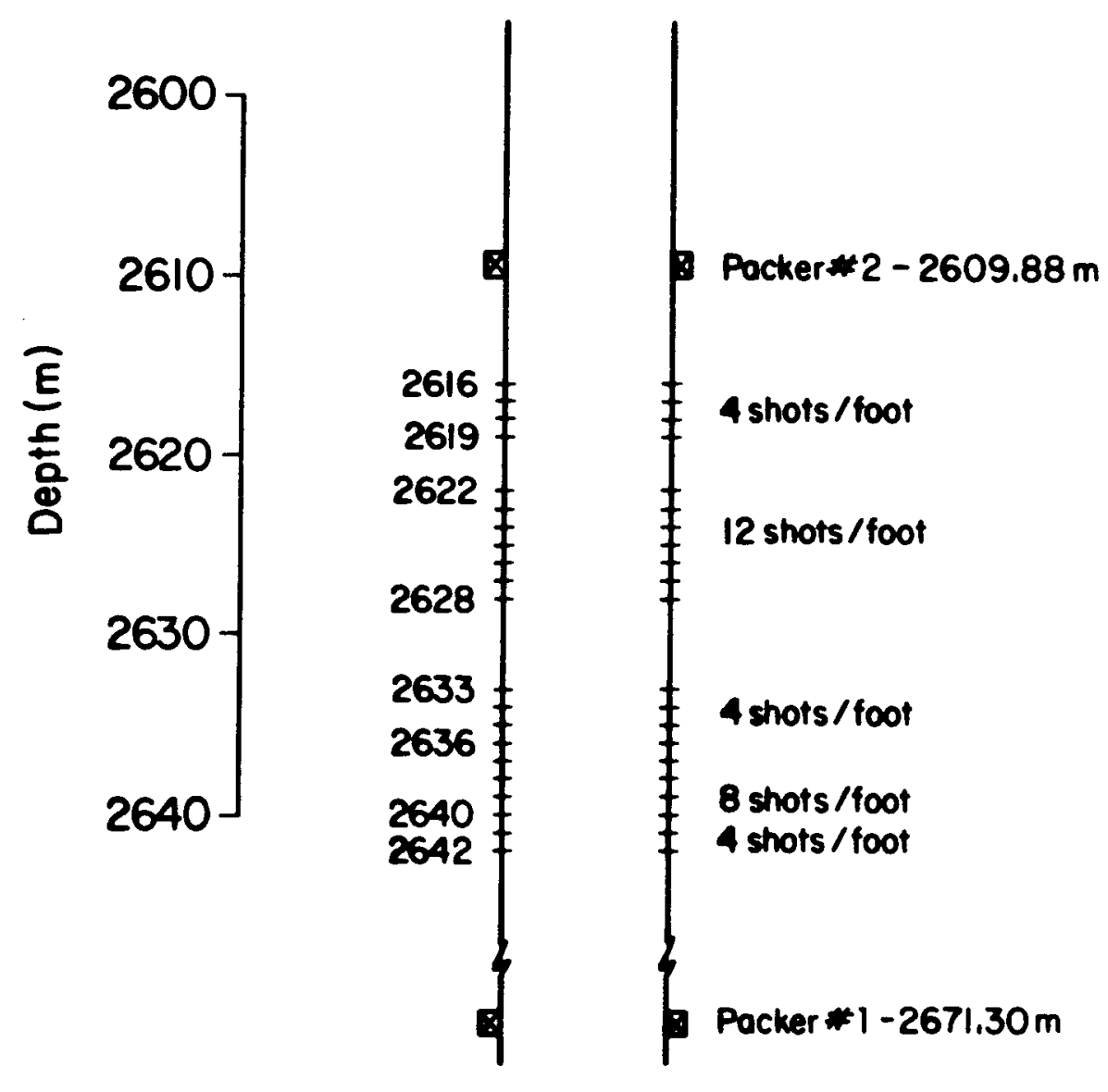

XBL848-9858

Figure 7. Perforated interval in Ashdod 3. 


\section{Injection Tests}

After the well began to accept fluid, two injection tests were performed. The first one, prior to acidizing the well, indicated an injectivity of approximately $0.1 \mathrm{~m}^{3} / \mathrm{hr} / \mathrm{meter}$ of water level buildup. A total of 720 cubic meters of brine were injected into the formation in a twelve-hour period. Unstable well performance, that is, rapid changes in the injection rate and pressure, suggested that the well was being plugged. $\mathrm{HCl}$ acid was injected into the formation in an attempt to improve the injectivity and stabilize the well condition. After the acid treatment, injectivity improved and another injection test was conducted. This injection test lasted approximately 4 hours and indicated that the injectivity increased to $1 \mathrm{~m}^{3} / \mathrm{hr} /$ meter of water level buildup. Interpretation of the test data was difficult because the effects of changes in the temperature of the wellbore fluid masked the actual pressure changes in the reservoir. Although the acid treatment appeared to improve the well condition, there were indications near the end of the injection test that the formation was plugging again. A total of approximately $1000 \mathrm{~m}^{3}$ of fresh water was injected into the formation during these injection tests.

\section{Airlift Test}

On June 28, 1981, an airlift test was carried out in well Ashdod 3. Approximately 2.5 $\mathrm{m}^{3} / \mathrm{hr}$ were lifted from the well with a drawdown of $200 \mathrm{~m}$, resulting in a productivity of $0.12 \mathrm{~m}^{3} /$ hour/meter of drawdown. The low productivity confirmed that the well was plugged and required remedial treatment before it could become a suitable test well.

\section{Well Stimulation}

All of the relevant well data were reevaluated in order to assess the most likely cause of formation damage so that the proper remedial treatment could be designed (Goranson, 1981; Sparlin, D., personal communication). The investigation indicated that permeability reduction resulted from plugging of vugs and fractures with bentonite, drill cuttings and 
cement. In addition, the perforations may have been plugged with cuttings and well bore cavings. A remedial treatment was designed to i) reopen the wellbore to the formation, ii) remove any drilling mud and cuttings from the formation, and iii) enhance the fracture permeability by increasing the fracture width. Ideally, an acid-fracturing treatment should be used in this situation. However, when the stimulation program was planned the lack of necessary equipment in Israel precluded this operation. Therefore, a large matrix-acidizing treatment, with deep penetration into the formation, was chosen as the next best alternative.

Originally, the primary target formations considered as potential geothermal aquifers were the dolomitic Zohar and Shderot Formations. The Karmon, separating the two, was thought to be impermeable. However, careful reevaluation of the geophysical logs and drilling data suggest that the Karmon is fractured and therefore, of potential interest. Stimulation intervals were chosen on the basis of the intensity of fracturing and/or presence of vugs. Three intervals were identified for treatment: 2615 to $2635 \mathrm{~m} ; 2645$ to 2655 $\mathrm{m}$; and 2672 to $2685 \mathrm{~m}$ depth.

Cores from wells Ashdod 3 and 4 were tested in order to find the most effective combination of acids and additives for a successful treatment. Because the permeabilities of the cores were so low (in the microdarcy range) it was necessary to induce fractures in the cores before the chemical tests could be conducted. A bentonite slurry was then injected into the cores to simulate the effects of loss of drilling mud circulation. Several acids and combinations of acids were injected into the cores, including: $\mathrm{HCl}$; $\mathrm{HF}$; acetic acid; and citric acid. A $10 \%$ acetic acid solution was the most effective for removing the drilling mud and increasing the fracture permeability. Tests indicated that $\mathrm{HCl}$ was extremely reactive with the formation and also effective in enlarging the fractures and vugs. Based on the results of these tests, a three stage treatment, using both acetic and $\mathrm{HCl}$ acids was designed (Sparlin, D., personal communication). First, a $10 \%$ acetic acid would be used to penetrate the mud filled fractures. A $15 \% \mathrm{HCl}$ solution, combined with $5 \%$ 
citric acid and a surfactant would then be used to rapidly enlarge the fracture openings. A final volume of $10 \%$ acetic acid, penetrating deep into the formation, would connect as many natural fractures and vugs to the wellbore as possible.

Due to the large interval to be acidized, the treatment was divided into two parts. First, the open hole interval ( 2672 to $2685 \mathrm{~m}$ ) would be acidized. Next, the upper interval, containing the zones between $2615-2635 \mathrm{~m}$ and $2645-2655 \mathrm{~m}$, would be reperforated with large diameter shots. This interval would then be acidized. Division of the treatment into two parts, though more costly than a single treatment, ensures a more even distribution of acid over the intervals of interest, thereby maximizing the chances of successful rehabilitation of Ashdod 3.

An estimated three to four weeks is required to complete the stimulation program. Costs for the treatment include i) rig time, ii) rental of fluid tanks, storage tanks, mixing equipment, pumping unit, and compressors, iii) chemical costs, iv) purchase of packers, and $v$ ) the cost of reperforating the liner with large diameter shots (approximately 1 inch). In 1982, the estimated cost of rehabilitating and testing (to evaluate the success of the well stimulation) well Ashdod 3 was between US $\$ 400,000$ and 500,000 . As cost estimates in the oil business change rapidly, a new cost estimate is required if this work is to be continued.

The chances of improving the condition of Ashdod 3 to the extent that it can be used as a test well are very good. However, this does not imply that the flowrates required for the desalination plant can be achieved by this procedure. This and the long term stability of the well treatment can only be determined after the well has been tested over an extended period of time. 


\section{Well Ashdod 4}

\section{Drilling and Completion}

Ashdod 4 was spudded on March 1, 1977 and completed to a total depth of $2685 \mathrm{~m}$ on May 23, 1977. The Zohar was drilled with complete circulation. When the Shderot Formation was penetrated, a partial loss of circulation occurred. Loss-of-circulation material was added to the drilling mud but did not prevent the total loss of circulation that occurred at a lower depth in the Shderot. The last $18 \mathrm{~m}$ of the well were drilled with no returns. A $95 / 8$ inch (40\# - k55) casing was set at a depth of $1928 \mathrm{~m}$ and cemented to the surface. After determining that the well was a "dry hole", it was abandoned.

\section{Recompletion}

Recompletion of Ashdod 4 began on March 3, 1981. A large amount of junk (e.g., iron plates, miscellaneous drilling equipment, etc.) was found in the well and resulted in serious delays in the recompletion. After removing all of the debris from the well, it was cleaned to a depth of $2663.5 \mathrm{~m}$ with drilling mud. A 7-inch (20\# - k55) diameter liner was set in the well to stabilize the hole and isolate the Sherdot Formation. Only two packers were set with the liner due to the poor condition and instability of the well. Isolation of the Zohar formation, for additional testing, will require the use of a rig to set a cement plug, squeeze off the liner, and perforate. A schematic of the final completion of Ashdod 4 is shown in Figure 8. After setting the liner, a bit was run down to $2699 \mathrm{~m}$. The hole was circulated clean with drilling mud. When the drilling mud was replaced by water, circulation was lost. A short injection test, discussed in the next section, was conducted before the rig was released on April 23, 1981. 


\section{(not to scale)}

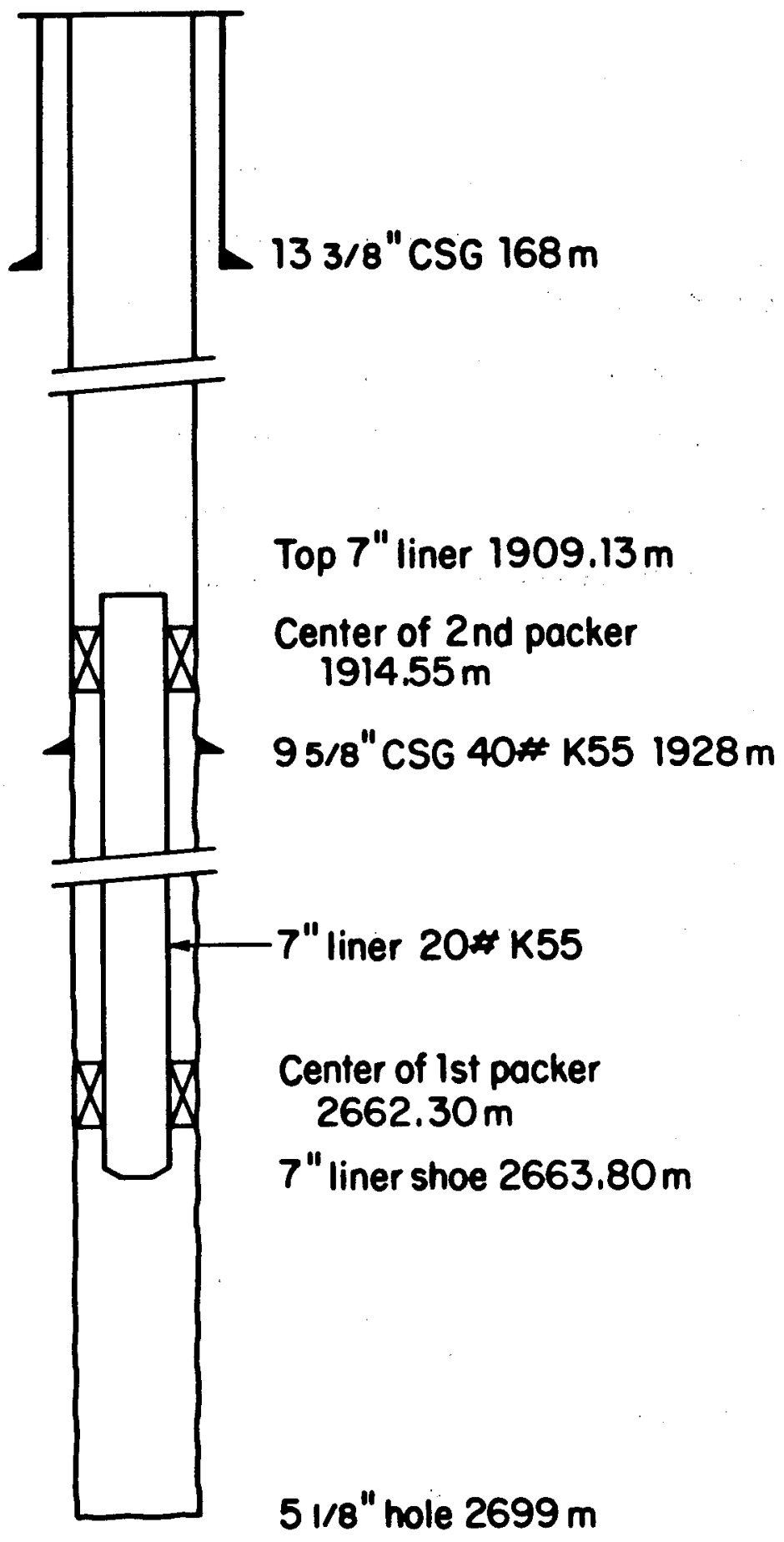

XBL848-9856

Figure 8. Ashdod 4 well construction. 


\section{Injection Teats}

A two-hour injection test was performed in the Shderot Formation penetrated by Ashdod 4 on April 19, 1981. Approximately 200 cubic meters of fresh water was injected into the formation during the test. Interpretation of the data was very difficult due to the effects of temperature changes in the wellbore fluid. However, an injectivity of 3 $\mathrm{m}^{3} / \mathrm{hr} / \mathrm{meter}$ of drawdown can be estimated from the test data. Two months later a second injection test took place. However, after one hour it was impossible to inject any water, even at a wellhead pressure of 1100 psi. Clearly, the well was plugged. The cause of plugging is uncertain. However, it appears to be related to injection of fresh water. This suggests that fresh water, when coming into contact with the formation, creates a chemical reaction that results in clay swelling or mineral precipitation. Until the success, or lack of success, of the stimulation treatment designed for Ashdod 3 is evaluated, it is difficult to determine the actual mechanism of formation damage occurring in the Ashdod wells.

\section{Summary}

The results of the recompletion of wells Ashdod 3 and 4 were very dissapointing. However, valuable information, though costly, was obtained from these operations. First, the problems encountered with recompletion cannot be considered as particular to these two wells. The difficulties must be considered indicative of the challenge of completing highproduction-rate wells in these formations. Loss-of-circulation, unwanted chemical reactions, and formation plugging will continue to be a problem until drilling practices, that prevent their occurrence, are developed. This fact cannot be overlooked when assessing the geothermal potential of these formations. Second, the choice to recomplete abandoned wells, as opposed to drilling new wells, must be reevaluated. Often, drilling reports do not contain all of the information required to evaluate the current status of a well (e.g., mud weights, fluid additives, quantities of materials used, debris in the borehole, etc.). 
The lack of this data can sometimes be costly and result in misinterpretatin of the source of the problems. Therefore, if this project is reinstated at some time in the future, serious thought should be given to starting with a new well(s). 


\section{CONCLUSION}

A hydrogeological model of the Jurassic formations, underlying the Ashdod area, has been developed. Three formations, beginning at a depth of $2575 \mathrm{~m}$ and with a thickness of over $150 \mathrm{~m}$, form a potential hydrothermal aquifer. Estimates of the areal extent of the aquifer range from 40 and 75 square $\mathrm{km}$. Temperatures in the aquifer range from 85 to 95 ${ }^{\circ} \mathrm{C}$.

Assessment of the hydrothermal potential of the Jurassic formations underlying the Ashdod area remains ambiguous. On one hand, the geologic data indicate that these formations are highly fractured and vuggy. Therefore, the prospects for pumping large quantities of brine from them is very good. On the other hand, almost all of the hydrologic tests have shown that wells tapping these formations are unproductive. The poor performance of these wells is attributed to formation damage and wellbore plugging, caused by drilling and completion practices. Certainly, this can partially explain the poor performance of the wells. However, with the available information, it is not possible to determine if the low well-productivity is only due to the completion practices or if in fact the formation permeability is low. The fact remains that drilling and completing high-productivity wells that tap these formations is difficult, at best. Until a well is drilled and completed in a suitable manner, it is not possible to unequivocally evaluate the hydrothermal potential of these formations.

The ecomonics of developing a hydrothermal resource, such as the one at Ashdod, rely heavily on having an end-use that is specifically suited to the resource at hand. For instance, the high cost of drilling, pumping the wells, treating the fluid, etc., precludes the use of this resource by an individual or small industrial firm. On the other hand, a user, with an application that specifically requires a large, low-grade heat source, such as the desalination plant, may benefit from developing the resource. As was shown in Table 1, the

cost of geothermal energy may be competitive with other sources. However, detailed economic analyses are premature until the possibility of drilling and completing high- 
$-34-$

productivity wells in this area is demonstrated. 


\section{REFERENCES}

Buchbinder, L.G., 1977. Facies, environment of deposition and correlation of the Zohar (Brur Calcarenite), Karmon and Shderot Formations in the Ashdod area. Geological Survey of Israel Report OD/3/79.

Derin, B., and Gerry, E., 1972. Jurassic biostratigraphy and environments of deposition in Israel. Preprint of the 5th African Micropal. col., Addis Ababa, Ethiopia. Also, Israel Institute of Perol. Micropal. Lab Report 2/72.

Goranson, C.B., 1981. A summary of wellbore/reservoir damage and treatment methods with relation to the Ashdod well field, Ashdod, Israel. Project report, joint U.S.-Israeli Desalination Project.

Earlougher, R.C., Jr., 1977. Advances in well test analysis. Society of Petroleum Engineers Monograph Series, Vol. 5.

Goldberg, M., and Bogoch, R., 1978. Dolomitization and hydrothermal mineralization in the Brur Calcarenite (Jurassic) Southern Coastal Plain. Israel Journal of Earth Sci. Vol. 27, pp. 36-41.

Gudmunsson, J.S., and Palmason, G., 1981. World survey of low-temperature geothermal energy utilization. Iceland National Energy Authority report 0S81005/JHD02, Reykjavik, Iceland.

Idaho Operation Office (IDO), 1982. Low-to-moderate temperature hydrothermal reservoir engineering handbook, Vol. 1 and Vol. 2. U.S. Dept. of Energy, Idaho Operations Office, report IDO-10099.

Koifman, L., 1979. Geothermal energy potential in the southern coastal plain. Israel Inst. of Pet. and energy Report.

Koifman, L., 1980. Possible utilizations of the geothermal energy potential in the Ashod Area. Israel Inst. of Pet. and Energy Report.

Mercado, A., and Simpson, B., 1981. Simulation of the transient behavior of low temperature geothermal wells (The GTWL Model). Tahal Consulting Engineers, Appraisal of Geothermal Brine Resources in the Ashdod Area, Technical Report No. 4.

Michelson, H., 1981. Hydrogeological reconnaissance of the Jurassic formation in the Ashdod-Gan Yavne area. Tahal Consulting Engineers. Appraisal of the geothermal brine resources in the Ashdod area, Technical Report 2.

Oil Exploration Investments Ltd. (OEL) 1976-1981. Geological Drilling and Completion Reports, Ashdod 1-6. Internal reports to OEL.

Starinsky, A., and Kac, A., 1978. Tracing of saline water movement in underground formations as an aid to oil exploration. Geology Department, Hebrew University Report to Israeli Dept. of Energy.

Warren, J.E., and Root, P.J., 1963. The behavior of naturally fractured reservoirs. Society of Petroleum Engineers Journal. September 1963, pp. 245-255. 


\section{ACKNOWLEDGEMENTS}

Sincere thanks are due to several individuals, in particular; to Leon Koifman, whose inspiration and hard work took this project from its conception through its present state; to Joseph Finke and Abraham Peled, whose support made this project a reality; to Abraham Mercado, whose lively conversation and excellent technical guidance kept the project on track and fnally, to Sherman Reed, whose patience and excellent management kept the project going smoothly. The assistance of Derry Sparlin, who provided technical input on the well stimulation treatment, is also gratefully acknowledged. This work was supported by the Joint U.S. - IsraeliPDesalination Project, which was co-sponsored by the United States Agency for International Development and the Israel Ministry of Energy and Infrastructure. 